\title{
Does Employing Older Workers Affect Workplace Performance?
}

\section{ALEX BRYSON (D), JOHN FORTH (D), HELEN GRAY (iD) and LUCY STOKES iD}

\begin{abstract}
Using a panel of workplaces in Britain, we investigate the implications for businesses of employing older workers. Workplace labor productivity falls where the proportion of older or younger workers rises. These raw associations are attenuated somewhat after controlling for aspects of human capital. In contrast, there is no significant association between age shares and workplace financial performance, suggesting that any reluctance by employers to employ greater numbers of older workers may be misplaced.
\end{abstract}

\section{Introduction}

The aging population and growing labor-force participation by older people means there is a shift in the age profile of those supplying their labor to employers in almost all developed economies (Organisation for Economic Cooperation and Development [OECD] 2019). In the UK, for instance, there have been sharp increases in economic activity rates among those aged 55 or more over the past two decades (George, Hilary, Leila, and David 2015) and

JEL codes: J21, J23, J24, J63, L25, M51.

*The authors' affiliations are, respectively, University College London, London, UK. E-mail: a.bryson@ucl.ac.uk; University of London, London, UK. E-mail: john.forth@city.ac.uk; Institute for Employment Studies, Brighton, UK. E-mail: helen.gray@employment-studies.co.uk; National Institute of Economic and Social Research, London, UK. E-mail: l.stokes@niesr.ac.uk. This research was funded by the UK Department for Work and Pensions (DWP). The authors acknowledge the Department for Business, Innovation and Skills; the Economic and Social Research Council; the UK Commission for Employment and Skills; the Advisory, Conciliation and Arbitration Service; and the National Institute of Economic and Social Research (NIESR) as the originators of the 2011 Workplace Employment Relations Study data, and the Department of Trade and Industry; the Economic and Social Research Council; the Advisory, Conciliation and Arbitration Service; and the Policy Studies Institute as the originators of the 2004 Workplace Employment Relations Survey, and the UK Data Archive at the University of Essex as the distributor of the data. The National Centre for Social Research was commissioned to conduct the survey fieldwork on behalf of the sponsors. None of these organizations bears any responsibility for the authors' analysis and interpretations of the data. The authors also gratefully acknowledge comments from participants at the 2018 Conference of the Work and Pensions Economics Group (WPEG) and the 2018 Applied Research Conference of the Chartered Institute of Personnel and Development (CIPD).

Industrial Relations, DOI: 10.1111/irel.12265. Vol. 59, No. 4 (October 2020). (c) 2020 The Authors. Industrial Relations published by Wiley Periodicals LLC on behalf of Regents of the University of California (RUC). Published by Wiley Periodicals, Inc., 350 Main Street, Malden, MA 02148, USA, and 9600 Garsington Road, Oxford, OX4 2DQ, UK.

This is an open access article under the terms of the Creative Commons Attribution License, which permits use, distribution and reproduction in any medium, provided the original work is properly cited. 
much of the recent growth in employment has been in this age group (George et al. 2015). These trends are expected to continue, with one in three workingage adults expected to be aged 50 or more by 2022 . While the United States has had legislation outlawing discrimination on the basis of age since the late 1960s, most countries in Europe have been slow to tackle such prejudice. The UK government, for its part, introduced legislation to outlaw age discrimination in employment in 2006 and removed the default retirement age of 65 in 2011. In recent years, it has engaged in a series of campaigns to challenge stereotypes and to emphasize the potential business benefits to employers of employing older workers and of adopting flexible approaches to work and retirement (Department for Work and Pensions 2007, 2017). The latest of these campaigns has set an explicit target of getting an additional 1 million older people into employment by 2022: the equivalent of an average employer increasing their number of older employees by 12 percent (Business in the Community 2017). That such campaigns should be needed reflects residual uncertainties among some employers about the net benefits of employing older workers.

In this article, we examine the relationship between the age composition of the workforce and workplace performance. More specifically, we consider whether changes in the proportion of older (and younger) workers employed at the workplace, as well as changes in age diversity, are associated with change in workplace performance. We use panel data for private-sector workplaces from the nationally representative British Workplace Employment Relations Survey (WERS) to explore whether changes in the age composition of the workforce are associated with changes in workplace performance, over the period 2004-2011. Workplace performance is measured according to managers' subjective assessments of workplace labor productivity, quality of product or service, and financial performance.

Evidence from existing studies on the relationship between workforce age and workplace performance is almost exclusively on productivity outcomes. In all but two studies (Garnero, Kampelmann, and Rycx 2014; Kunze, Boehm, and Bruch 2011), the dependent variables are confined to a measure of labor productivity (either sales, value added, total factor productivity [TFP], or scrap rates) and so can tell us nothing about the impact of age-related factors on firms' overall performance or profitability. Existing studies also focus exclusively on the average age of the workforce and so are unable to comment on the specific impact of older workers. ${ }^{1}$ We contribute to the literature in four

\footnotetext{
${ }^{1}$ An increase in the average age of employees at the workplace could arise through an influx of older workers-as the UK government's targets intend-or through the exit of young workers with no change in the numbers in older age brackets.
} 


\section{4 / BRYSON ET AL.}

ways. First, in addition to analyzing productivity outcomes, we extend the range of performance measures to include financial performance which, we assume, is what private-sector workplaces are seeking to maximize; we also examine product or service quality. Second, we look separately at the impact of older and younger workers, relative to those in middle age; this allows us to speak more directly to policy, which is focused explicitly on the upper end of the age distribution. Third, we focus on the role that various facets of human capital may play in explaining any association between workforce age and workplace performance. In doing so, we are able to account for a number of potential time-varying confounding variables, such as other aspects of workforce composition and the quality of management, as indicated by an index of human resource management practices. Finally, to our knowledge, our analysis is the first to explore the relationship between workforce age and workplace performance using nationally representative data for British private-sector workplaces.

We find no significant associations between changes in the proportion of older workers employed and changes in workplace financial performance. Changes in age diversity also show no association with changes in financial performance. This suggests that overall the age composition of private-sector workplaces does not have a sizeable role to play in explaining business success. However, we do find evidence that workplace labor productivity falls where the proportion of workers aged 22-49 falls, either due to a rise in the proportion of older or younger workers. The association between a fall in the proportion of workers aged 22-49 and falling workplace labor productivity does not carry through to financial performance. One possible explanation is that workplaces benefit from older or younger workers in other ways, perhaps, for example, by reducing labor costs. However, our findings are unchanged when we additionally account for change in hourly wages, a key component of labor costs.

In the remainder of the article, we first review the existing evidence regarding the association between the employment of older workers and workplace performance. We then set out the key features of the data used in the study and the approach to identifying older workers. The measures of workplace performance are described as are the methods used to capture the relationship between the employment of older workers and workplace performance. The results of the analysis are presented and the article concludes with a summary of key findings.

\section{Existing Evidence on Older Workers and Workplace Performance}

Provided employers do not engage in direct or indirect age discrimination in hiring and firing, the laws governing equal treatment allow employers some 
discretion over the age composition of their workforce. Equal treatment legislation does not prescribe quotas. Consequently, the employment of older workers is largely an employer "choice" at the margin and there are numerous cases of employers actively pursuing older job seekers (Craig 2009). Because employers are usually assumed to be profit maximizing — at least in the market sector-we can assume that this choice is made with reference to the costs and benefits of employing older workers, as opposed to younger workers (either in their middle age or youth) or no workers at all. ${ }^{2}$

In a standard economic framework, it is assumed that employers combine factors of production efficiently such that they will continue to recruit older workers until their marginal productivity means it is no longer optimal to do so. If employers have optimized, then the share of older workers at the workplace will be neither positively nor negatively correlated with performance outcomes. However, there are a number of reasons why we might expect the share of older workers employed at workplaces to not be optimal. First, labormarket frictions such as the costs of matching workers to job slots mean that the actual number of older (or younger) workers employed at a given time may not reflect what might be best for the workplace. For example, it may be that there is a shortage of relevant job seekers in the local labor market in which the employer is recruiting. Second, employers may lack knowledge about the value of older workers and their effect on workplace performance. This lack of knowledge or information about the value of older workers may arise from biased assumptions about their likely skills and abilities. Indeed, correspondence studies consistently indicate that employers unfairly discriminate on the basis of age, particularly as workers approach the traditional retirement age (see Neumark, Burn, and Button 2019 for recent evidence and a review of previous studies).

In these circumstances in which some employers have too few older workers, we would expect to see a positive correlation between the share of older workers and workplace performance. However, it may be the case that some employers will benefit more than others from having a high share of older workers. For example, where the customer base for a product or service consists primarily of older people, firms may choose to serve those customers with older workers, in the belief that similarities between the seller and buyer may enhance customer satisfaction or increase sales. Alternatively, in firms that rely on employees having high levels of firm-specific human capital it may make

\footnotetext{
${ }^{2}$ It is sometimes stated that rising labor-market participation by older people restricts employment opportunities for younger people. However, there is little evidence to support this argument. While at a firm level an employer may weigh the costs and benefits of employing older or younger workers, the number of jobs in the economy as a whole is not fixed (what economists term the "lump of labor fallacy").
} 


\section{6 / BRYSON ET AL.}

sense to retain a higher share of older workers who have had the time to build up that firm-specific knowledge.

There is a growing literature on the relationship between workforce demographics and organizational performance. Much of this literature has been concerned with the effects direct and indirect discrimination have in limiting the talent pool available to employers, which may adversely affect organizational performance. ${ }^{3}$ This concern has prompted research into the impact of increasing the presence of under-represented groups in the workforce, including recent studies on the gender mix of corporate boards. ${ }^{4}$ The implication is that the talent of some parts of the population is being underutilized, such that their representation in the labor market is suboptimal from the perspective of both firms and society.

However, most of the empirical literature on the link between the demographic characteristics of the workforce and organizational performance does not focus on discrimination. Instead, it is concerned with the potential value of workforce diversity to employers, and the effects of changing workforce composition on organizational performance. The dual focus in the literature-on employee shares and workforce diversity - is important because both may have effects on organizational performance, at least in theory.

A workplace's age composition refers to the proportion of employees in the workplace belonging to different age groups. A workplace's age diversity captures the spread of workers across the age distribution. This is sometimes captured using the standard deviation in workers' ages, or the coefficient of variance (the standard deviation divided by the mean). An alternative metric, which is the one we use in this study, is a Herfindahl index. It is related to workforce composition but combines two quantifiable measures: the number of age categories used to distinguish employees on the age dimension, and the proportion of the workforce that falls into each category.

Workplace performance may benefit from increasing the share of older workers for several reasons. A key tenet of human capital theory is that individuals accumulate human capital over the life cycle, becoming more productive as they learn from their work experience (Becker 1962; Rosen 1972). Such experience enables workers to become more proficient at job tasks, to learn new skills, and to assimilate working routines, thereby becoming more productive with age in various settings. In his original formulation of human

\footnotetext{
${ }^{3}$ One of the earliest examples of employers recognizing the adverse effects of discrimination on their performance is Goff, McCormick, and Tollison's (2002) account of the way in which black players were assimilated into professional baseball and basketball in the United States.

${ }^{4}$ For example, see Bertrand et al. (2014) for an examination of the effects of female quotas for corporate board membership in Norway.
} 
capital theory, Becker (1962) also drew particular attention to firm-specific human capital as that which raises the productivity of a worker at the current firm, but not elsewhere. Workplaces may benefit from the increased firm-specific human capital that older workers acquire through the long-term investments they make in the firm, usually captured in their tenure at the workplace. For example, if firms become increasingly reliant on firm-specific knowledge and "corporate memory" - as might be the case in a situation in which a firm is moving toward the production and sale of more specialized goods or services not readily available elsewhere in the market - their need for workers with considerable experience in that firm may grow. Alternatively, if an employer's customer base is aging, firms may find that "matching" their staff profile to that of their customers enhances customer satisfaction or increases sales. These potential benefits are based around the conception of older workers' specific "productive assets" (Gratton and Scott, 2016).

Conversely, an increase in the percentage of older workers employed at a workplace may adversely affect workplace performance if the workplace is reliant on employees who are physically very fit and agile, or in circumstances in which older workers are slower at adopting new procedures or technologies introduced by the firm. These putative disadvantages of older workers-partially concerned with their "vitality assets" (Gratton and Scott, 2016) - tend to invoke a certain characterization of the older worker (less agile, technophobic, or more prone to absence or illness) which, some argue, might be outdated and not necessarily linked to age per se.

The link between workforce diversity and organizational performance is also theoretically ambiguous. This is because there are potential costs as well as benefits to workforce diversity, so that any overall effect is likely to reflect the net outcome from potentially competing mechanisms. ${ }^{5}$ Diversity may increase production in teams in which they can improve knowledge sharing, enhance decision making, lead to increased problem-solving capacity, and result in more creativity. It can also affect worker performance via well-being: if greater diversity is preferred-that is, workers derive greater utility from being in a more diverse workforce - this may feed through to workers' productivity and thus firm performance. However, the opposite may happen if workers derive greater utility from working alongside others who are "like them." Greater diversity can also entail increased costs in situation in which it increases problems of coworker communication or lowers cooperation (for instance, through lower trust relations or weaker social ties). The degree to which organizations will derive benefits from greater diversity will depend on the extent to which

\footnotetext{
${ }^{5}$ For an excellent review of this literature and its empirical counterpart see Ilmakunnas and Ilmakunnas (2011). Our brief comments draw, in part, on their review.
} 


\section{8 / BRYSON ET AL.}

the skills and knowledge of older and younger workers are complementary, or if there are spillovers across different worker types, as may be the case in situations in which younger workers can learn from older workers (either informally or via formal mentoring). Lazear (1998) argued that age-related complementarities derive from the fact that younger employees tend to have greater knowledge of new technologies while older employees have better understanding and experience of operational matters.

These considerations suggest that the performance effects of age shares and age diversity are likely to vary across workplaces according to their production technologies and worker preferences. The latter are very difficult to establish, the former less so. At one extreme, age diversity will have negative effects on firms in which production is characterized by workers of similar skills performing tasks together. ${ }^{6}$ At the other extreme, gains from diversity will be greatest where complementarities across different types of worker are high and information can be learned at low cost (Lazear 1999).

None of the above refers directly to dynamic organizational settings in which the age composition of the workforce is changing. These changes can present their own challenges, as described in Kunze, Boehm, and Bruch (2011), who found increased age diversity can result in increased perceptions of age discrimination. In turn, this can undermine organizational affective commitment, thus reducing organizational performance. It is possible that such effects may be mitigated by appropriate equal opportunities policies which monitor and review age-related aspects of recruitment, promotion, and rewards.

Table 1 summarizes empirical evidence regarding the links among age, age diversity, and organizational performance. ${ }^{7}$ All studies incorporate both age diversity measures and average age or age-share measures, though their precise derivation varies across studies. In all but two studies (Garnero, Kampelmann, and Rycx 2014; Kunze, Boehm, and Bruch 2011), the dependent variables are confined to a measure of labor productivity (either sales, value added, TFP, or scrap rates) and so can tell us nothing about the impact of age-related factors on firms' overall performance or profitability. This is an issue to the extent that older workers may be either less or more costly than younger workers, depending on their bargaining power and the importance of seniority wage setting in firms. The effects of age and age diversity on organizational

\footnotetext{
${ }^{6}$ Referred to in the literature as O-ring production functions (Kremer 1993).

${ }^{7}$ The table does not contain all empirical studies ever conducted. Instead studies are chosen based on the quality of the data, the robustness of estimation methods used, and the possibility of extrapolating from the results more broadly.
} 
Older workers and workplace performance

/ 539

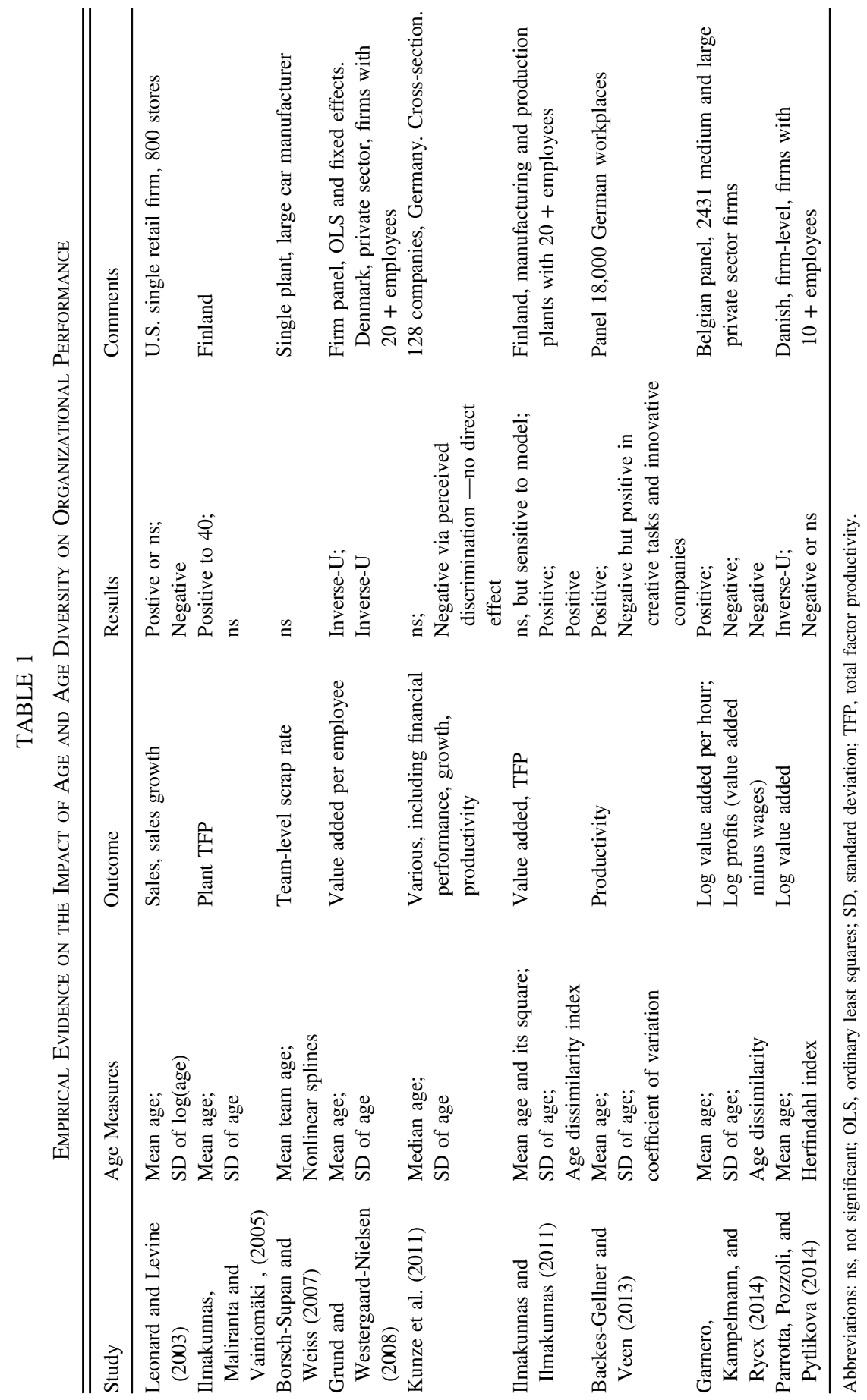




\section{0 / BRYSON ET AL.}

performance might conceivably switch once those cost-related factors are taken into consideration.

It is notable how disparate the findings are, reflecting differences in samples and settings, but also perhaps the countervailing theoretical impacts that age and age dispersion are likely to have on performance. Older average age, or a higher percentage of older workers, is not normally negatively associated with performance; it is positive and robust in Garnero, Kampelmann, and Rycx's (2014) study of Belgian private-sector firms and Backes-Gellner and Veen's (2013) study of German workplaces, while it has a nonlinear effect in Grund and Westergaard-Nielsen (2008) and Parrotta, Pozzoli, and Pytlikova (2014). Age diversity is positively linked to productivity in Ilmakunnas and Ilmakunnas's (2011) Finnish study but is negatively linked to sales in Leonard and Levine's (2003) U.S. retail firm and to profitability in Garnero, Kampelmann, and Rycx's (2014) Belgian study. Elsewhere, age diversity has either no significant effect, effects that are not robust across specifications, or an inverse-Ushaped relationship with organizational productivity.

Some of the studies are notable for testing theoretical propositions. BackesGellner and Veen (2013) build on Lazear's (1999) framework arguing that increasing marginal costs to age diversity and decreasing marginal returns will result in an inverse-U-shaped relationship between age diversity and productivity. They further argue that the optimal point in that the inverse- $U$ shape will be low in settings characterized by routine tasks but high in settings characterized by creative tasks. Their empirical evidence supports these propositions. As noted earlier, Kunze, Boehm, and Bruch (2011) outlined ways in which increasing age diversity can lead to increased perceptions of age discrimination, lowering affective organizational commitment which, in turn, decreases productivity. They found support for this model in their cross-sectional data using a structural model. Furthermore, they found no direct effect of age dispersion on productivity.

All of the studies in Table 1 utilize a measure of the average age of the workforce (typically the mean) alongside some measure of the spread (typically the standard deviation). While a focus on average age serves to indicate a general shift in the distribution in one direction or another, such movements can arise through subtly different routes. For instance, in most workplaces, an increase in average age is likely to arise through the hiring of anyone over the age of 40, whereas policy initiatives are typically focused on raising employment prospects for those closer to the traditional retirement age.

Finally, while the studies reviewed cover an array of workplaces and firms from different countries, none are conducted for Britain and none assess the association between the share of young and old workers and workplace performance or profitability. The analyses presented in the remainder of this article 
are the first to do so. We assess the association between workforce age and workplace productivity and financial performance and, in doing so, we differentiate between the impact of employing younger and older workers. Our findings thus add to the limited range of countries explored in the extant literature, and to the limited number of studies using nationally representative data, thereby furthering our understanding of the links between the age of the workforce and workplace performance.

\section{Data and Methodology}

Data. The primary data source for this analysis is the British Workplace Employment Relations Survey (WERS; Department for Business Innovation and Skills 2015). ${ }^{8}$ WERS is a large nationally representative survey of workplaces in Britain with five or more employees, covering all industries with the exception of agriculture, forestry, and fishing and mining and quarrying. At each wave, the survey collects data from a face-to-face interview with the human resource manager at the workplace, covering workforce composition (including the age distribution), workplace management practices and procedures, and various measures of workplace performance. Each wave also has a linked survey of employees within participating workplaces, collecting data on their human capital and wages, among other things. While each wave of the survey generates a cross-sectionally representative sample of workplaces, a subset of workplaces from each wave are followed up at the next to form a two-wave panel.

Our analysis is based on the 2004-2011 panel of private-sector workplaces within WERS. These workplaces had at least five employees in 2004 and 2011 when they were surveyed and were continuously trading throughout the period. We observe shifts in the share of older workers for workplaces that survived and were sampled over the period 2004-2011. ${ }^{9}$ We establish how

\footnotetext{
${ }^{8}$ For further information on WERS, see the website here: http://www.wers2011.info/

${ }^{9}$ Overall, 20 percent of private-sector workplaces surveyed in 2004 had closed by 2011 . We ran models predicting the likelihood of closure with 2004 workplace covariates including age shares and age diversity. Higher shares of very young workers (those aged below 22 years) were associated with a lower probability of closure. Specifically, an increase in the share of very young workers from the median to the seventy-fifth percentile (an increase of 13 percentage points) would reduce the closure probability from 0.23 to 0.18 (a reduction of 5 percentage points). Outside of this very young group, the balance between middle-aged workers (aged 22 to 49) and older workers (those aged 50+) was not associated with the probability of closure. Age diversity in 2004 was not predictive of closure by 2011. These patterns suggest that workplaces with higher shares of very young workers will have been slightly over-represented in the panel sample of surviving workplaces. One possible explanation is that very young workers are located in emerging industries in ways that are not wholly captured by our one-digit industry controls.
} 


\section{2 / BRYSON ET AL.}

these within-workplace movements in the share of older employees are linked to workplace performance (labor productivity, product quality, and financial performance), taking account of other time-varying features of the workplace such as workplace size and the management practices deployed at the workplace. We focus on the private sector because it is subject to market forces and, as such, employers in that sector are more likely to weigh the costs and benefits of employing older workers in the manner envisaged by theory. ${ }^{10}$

The private-sector subsample of the WERS 2004-2011 panel provides management interview data for a total of 633 workplaces, falling to approximately 500 workplaces after excluding workplaces with missing values on the performance indicator in question or missing data on the age composition of the workforce. Sample sizes are further reduced (to approximately 350 workplaces) once we condition on workplaces that provide data from the linked survey of employee in both waves of the panel. ${ }^{11}$

Unless otherwise stated, all analyses are survey weighted using workplacelevel sampling weights which adjust for the probability of sample selection and panel attrition. The basic survey weights are described by van Wanrooy et al. (2013) and provided with the survey data, but we incorporate additional nonresponse adjustments to account for selection into the estimation sample. ${ }^{12}$ The weighted data allow us to extrapolate the findings to the population from which the sample was drawn, namely private-sector workplaces with five or more employees that survived the period 2004-2011.

Identifying older workers. Managers participating in WERS are asked to report the number of employees in their workplace in each of the following age bands: 16-17, 18-21, 22-49, and 50 and above. This information is collected through the Employee Profile Questionnaire, which is distributed to

\footnotetext{
${ }^{10}$ That said, it is arguable that public-sector organizations are facing increasing pressures to deliver services efficiently to tight budgets and, as such, will be in a similar to position to workplaces in the private sector. This is an issue that could be tackled in future research.

${ }^{11}$ As described later, in the discussion regarding Equation 1, we use data from the linked employee survey to provide some of our control variables. Interviewers sought to distribute employee questionnaires in each participating workplace, but some managers refused and, in other workplaces, no responses were received from sampled employees.

${ }^{12}$ We run probit regressions to predict membership of the estimation sample for each performance indicator and use the inverse of the predicted probability to adjust the basic panel survey weight, which already accounts for panel attrition. These nonresponse adjustments to the survey weights are relatively minor: the pairwise correlation between the basic survey weight and our adjusted weight is 0.93 in the case of labor productivity and financial performance, and 0.96 in the case of quality.
} 
managers prior to a face-to-face interview, allowing them time to consult their records, which should improve the accuracy of the data collected.

We use the term "older workers" to refer to employees aged 50 and over. There is no consensus on what age constitutes being an "older worker," with a range of definitions in existence (Burgmann 2013). However, previous UK studies have also adopted the definition of aged 50 and above (e.g., Yeomans 2011, in a review of the literature on age and employment; Canduela et al. 2012, Smeaton, Vegeris, and Sahin-Dikmen 2009, among others). Many UK government statistics relating to older workers have also been produced on the basis of those aged 50 and over, although these sometimes additionally distinguish those aged 50 to 64 from those aged 65 and over (Department for Work and Pensions 2015; Office for National Statistics [ONS] 2015).

We define younger workers as those aged between 16 and 21. As for older workers, there are various definitions of "younger workers" in use, although it is fairly common for this to encompass a broad age group. Labor-market statistics produced by the UK's statistical office, for example, identify young people as those aged 16 to 24 (ONS 2016).

We also draw comparisons with workers aged between 22 and 49 years of age (i.e., all employees who are not categorized as younger or older workers, based on the definitions above). In practice, in many studies, the definitions of older and younger workers used reflect the information that is available in the data being analyzed, and our study is no exception.

The analyses use two age-related measures: the share of employees in one of three age brackets (50 or more, under 22, and those aged 22 to 49 years) and the Herfindahl index based on the number of age categories used to distinguish employees on the age dimension, and the proportion of the workforce that falls into each category. The Herfindahl index is calculated as follows:

(1-(( shareold* shareold $)+\left(\right.$ shareyoung* ${ }^{*}$ sharey-

oung $)+\left(\right.$ sharemid* ${ }^{*}$ haremid $\left.)\right)$.

where "shareold" is the share of employees in the workplace aged 50 or more, "shareyoung" is the share aged between 16 and 21, and "sharemid" is the share aged 22 to 49 years. The index has a minimum value of 0 if there is only one category represented within the workplace and, in the case with three categories, a maximum value 0.667 if all categories are equally represented.

In 2004, the workplace mean share of older workers employed in the panel of workplaces was 0.22 (see Table A1 in the Appendix). This had risen to 0.27 by 2011 . The median workplace witnessed an increase of 5.5 percentage points in the share of older workers at the workplace. The workplace mean for the share of young workers at the workplace fell marginally (from 0.10 to 
Within-Workplace Changes in Age Shares and Age Diversity, 2004-2011, Private Sector.
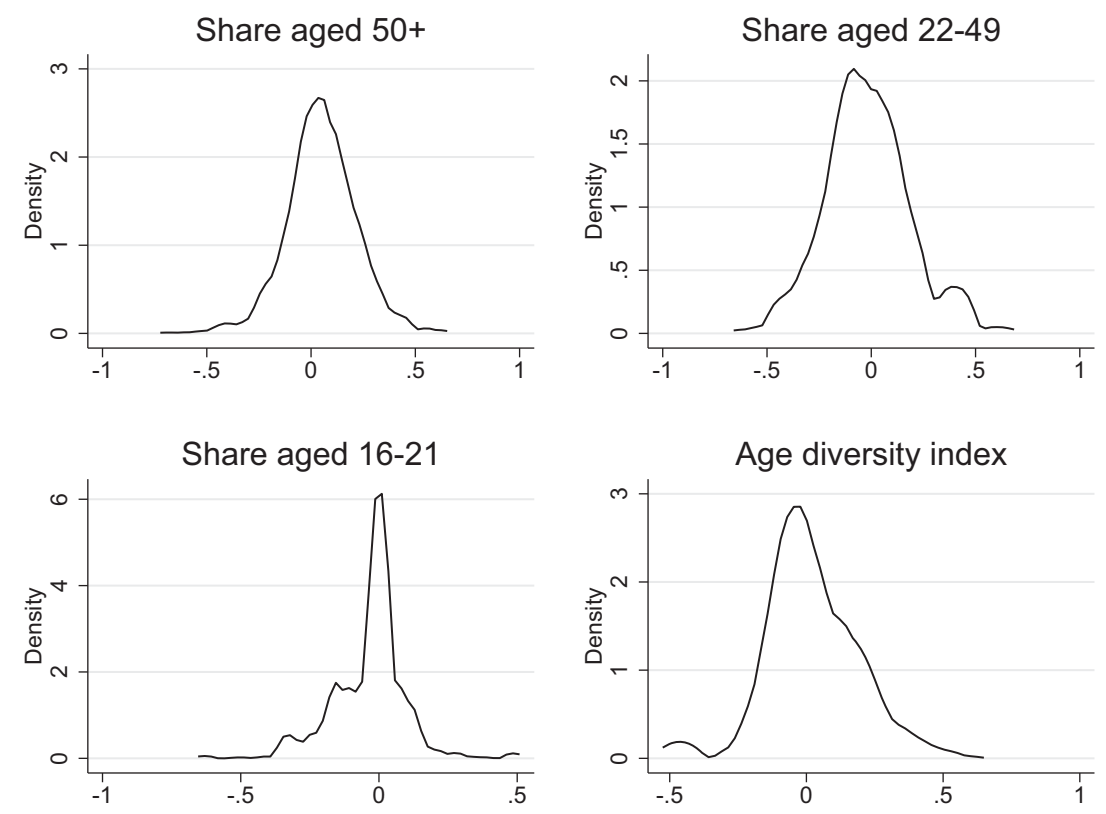

Source: Workplace Employment Relations Survey

0.08). At the median the change was zero. The two panels on the left of Figure 1 indicate much more dispersion in the change in older employee shares at workplaces compared to the fairly compressed dispersion of change in the share of young employees.

Mean age diversity increased slightly (from 0.39 in 2004 to 0.43 in 2011) but, as the bottom panels of Figure 1 indicate, there is substantial variance in the change in age diversity within workplaces over time with the distribution skewed slightly to the right.

Both the age share measures and age diversity measure are included in the models presented in this article, following the practice adopted in the rest of the literature reviewed above. Although the two sets of measures are positively correlated $^{13}$ the associations between age shares and workplace performance are robust to the exclusion of the age diversity measure.

\footnotetext{
${ }^{13}$ In our estimation sample the Herfindahl index and the share of older workers have a correlation coefficient of 0.48 (see Table A3 in the Appendix), which is statistically significant at the 1 percent level.
} 
Measuring workplace performance. The analysis examines three measures of workplace performance, namely labor productivity, the quality of goods and services produced, and financial performance. The measures rely on the workplace human resources (HR) manager's subjective assessment. The managerial respondents to the survey were asked: "Compared with other workplaces in the same industry how would you assess your workplace's ... financial performance, labor productivity, and quality of service or product?"

For each of the three questions, they chose one of five responses presented to them on a show card ranging from "a lot better than average" to "a lot below average." The percentage of managers saying their workplace performance was "a lot below average" was very small, so these responses were combined with those saying "below average" to form a 4-point scale (in which 1 represents "below average" or "a lot below average" and 4 represents "a lot better than average"). The three subjective workplace performance measures are, unsurprisingly, positively correlated such that those scoring high on one indicator tend to score high on the other two. ${ }^{14}$

The distributions for the three subjective measures of performance (labor productivity, quality of output, and financial performance) are presented in Figure 2. There is substantial persistence in the performance of workplaces. Approximately two-fifths report no change between 2004 and 2011 relative to the industry average. ${ }^{15}$ Nevertheless, there is substantial movement among the remainder with approximately one third reporting a deterioration in performance on all three measures and approximately one quarter reporting improvement relative to the industry average.

When investigating workplace influences on performance it is more conventional to rely on accounting measures such as sales per employee and value added per employee. They have the advantage of being measured along a cardinal scale against which one can readily quantify correlations with other workplace factors. Although WERS collects such measures through its Financial Performance Questionnaire (FPQ) we prefer to focus on the subjective measures of workplace performance for two main reasons. First, a much higher percentage of workplace managers feel able to provide an answer along the ordinal scale used for the subjective rating questions. Ninety percent of panel workplaces were able to do so on all three subjective performance measures in both 2004 and 2011, whereas the number of responses to the FPQ was low and item nonresponse was high (only

\footnotetext{
${ }^{14}$ The correlation coefficients in the weighted data are: financial performance and labor productivity 0.44 ; financial performance and quality 0.35 ; labor productivity and quality 0.33 . They are all statistically significant at the 1 percent level.

${ }^{15}$ In the case of financial performance the percentage is 39 percent, for labor productivity it is 41 percent, and for quality of output it is 47 percent.
} 

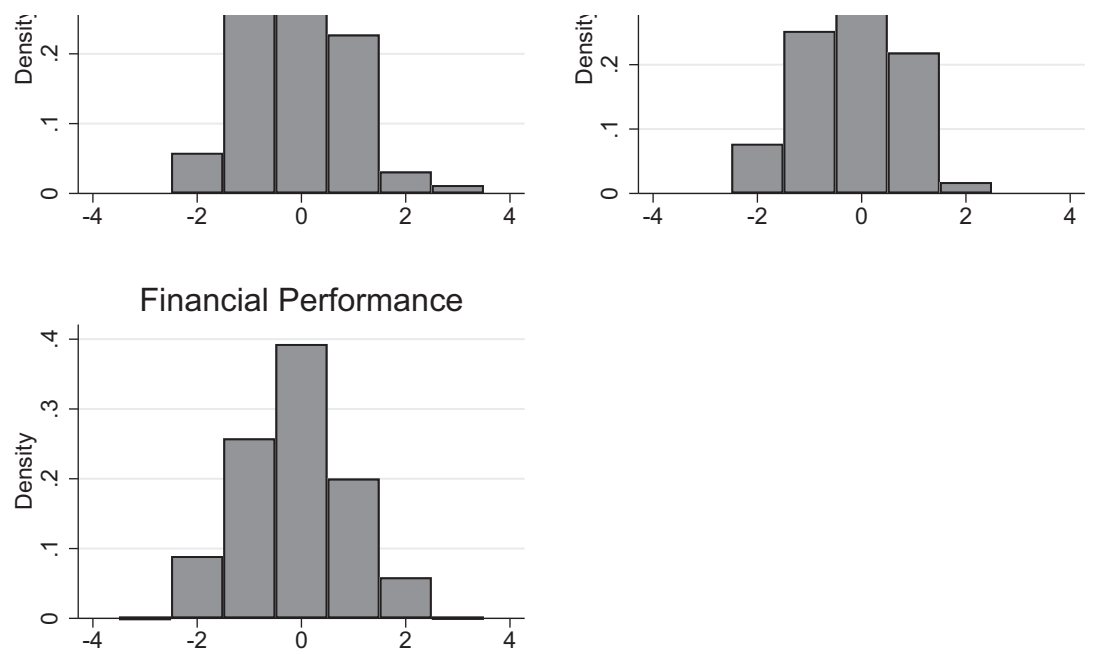

Source: Workplace Employment Relations Survey.

18 percent of panel workplaces returned an FPQ in both years and only 11 percent provided sufficient information to compute value-added per employee). One reason for the high rate of nonresponse to the FPQ may be reticence to disclose financial data that is not already in the public domain. The second reason for relying on the subjective assessments is that earlier studies have validated the subjective performance measures, confirming that they are predictive of subsequent workplace closure, for example, and are associated with other workplace features in the way theory might predict (Forth and McNabb 2008; Machin and Stewart 1990, 1996). ${ }^{16} \mathrm{~A}$ third potential advantage of the subjective measures is that managers are asked about performance relative to other workplaces in their industry, and therefore this should take account of any common industry shocks, which may be correlated with changing age composition. ${ }^{17}$

\footnotetext{
${ }^{16}$ In our estimation sample those reporting poorer financial performance in 2004 were more likely to have closed by 2011 .

${ }^{17}$ We nevertheless undertook analyses of accounting measures of labor productivity (gross value added per full-time equivalent) and financial performance (profit as a share of turnover) for the small number of panel workplaces (approximately 60) that provided the requisite information along with information on the age of their workforce. We regressed each measure of performance on the three age-related variables (share older workers, share young workers, and age diversity). All coefficients were imprecisely estimated, but the signs of those coefficients were entirely consistent with those shown in Table 2 and Table 4 in the main body of the article.
} 
Methods. We undertake multivariate analyses of the panel component of the WERS data to identify independent associations between the variables of interest. These analyses, which are also survey weighted to permit extrapolation to the population of workplaces at large, allow us to take account of the contribution of multiple factors, but it should be noted that such analyses can identify associations but not causal relationships.

The panel consists of workplaces that were observed in both 2004 and 2011. An advantage of using the panel data, rather than the two cross-sections, is that it allows us to look specifically at change within the same workplaces over time. One potential drawback is that the panel consists of a relatively small sample of workplaces, particularly once we restrict our attention to those workplaces with linked data from the Survey of Employees (from which we derive some of our controls). The nature of the panel data also means we only observe workplaces at two points in time, and over a period in which the economy experienced a significant downturn. It is possible that exploring change over a longer timeframe could produce different results; the availability of just two time points also limits our ability to identify the direction of any relationship with certainty.

We estimate first-difference panel models, which simply regress changes in our performance measures for workplace $i\left(\Delta p_{i}\right)$ on changes in age shares $\left(\Delta S_{i}\right)$-with the share aged 22 to 49 years omitted as the reference categorychange in age diversity $\left(\Delta D_{i}\right)$, and other time-varying workplace-level covariates captured in the vector $\Delta X_{i}{ }^{18}$ This vector consists of five blocks of control variables, three of which capture aspects of human capital, one capturing changes in other aspects of workforce demographics, and one capturing changes in managerial practices. We describe each in turn briefly below. More extensive descriptions of these variables, together with summary descriptive statistics for the estimation sample are provided in Appendix Table A1.

The first block of human capital variables proxy some of the Mincerian-type variables Becker (1962) had in mind when first elaborating the concept of human capital. These are employees' mean workplace tenure, their mean level of academic qualifications, the share of skilled workers (as indicated by the percentage of employees in the managerial, professional, technical, and skilled crafts occupations), and the share of employees underskilled for their jobs. Together these capture attributes that could be referred to as employees' "productive assets." The second set of human capital variables are the share of employees with longterm, work-limiting disabilities, and the share absent in the last year. If older workers are more prone to long-term health problems and absence than their

\footnotetext{
${ }^{18}$ In a two-period model such as ours, first difference and workplace fixed effects models are identical.
} 


\section{8 / BRYSON ET AL.}

younger colleagues, controlling for these "health-related assets" may weaken any negative association that might otherwise be evident between the share of older workers and workplace performance. The third set of human capital-relevant variables capture the degree to which the workplace relies upon employees with good information communication technology (ICT) skills (the percentage using computers in their daily work) and the degree of workplace innovation that employees must contend with (as indicated by a count of the number of workplace innovations management had introduced in the previous 2 years). If older workers lack the relevant ICT skills or are less able to cope with rapid change at work, as some contend, controlling for such variables may again reduce the size of any negative association between older workers and workplace performance that might be apparent in the absence of such controls.

The block of variables capturing workforce composition consists of: the total number of employees at the workplace, the share female, gender diversity, the share non-white, the share part time, and the percent union membership. Controlling for changes in other aspects of workforce composition helps to capture the relationship between changes in performance and age-related changes, thus helping to tackle any biases in the age-performance relationship that might occur through the omission of other workforce composition changes. ${ }^{19}$ Changes in union density are controlled for because these are known to affect workers' bargaining power which, in turn, can affect workplace performance. Because older workers are more likely to be unionized, failure to account for unionization rates could bias estimates of age-related coefficients on workplace performance.

Finally, we introduce a variable capturing the degree to which the workplace implements human resource management (HRM) practices intensively. We identify ten HRM practices that are commonly cited in the literature on workplace productivity (e.g., Appelbaum et al. 2000; Bloom and Van Reenen 2011), code dummy variables to indicate whether the workplace uses each of these practices, and then construct an additive scale running from 0 to 10 , with workplaces scoring each time they have one of the ten identified practices. Higher scores on the index thus correspond to more intensive use of such practices. The index first comprises practices which help the workplace to develop its human capital (whether at least 80 percent of core employees received off-the-job training in the past year and whether the workplace holds an Investors in People award - an accreditation framework for firms' training and development activities). The index then comprises practices which motivate its workers to contribute toward organizational success (whether at least

\footnotetext{
${ }^{19}$ Of course, it is possible that there are changes in other aspects of workforce composition that we do not control for here (such as changes in the proportion of non-UK nationals, for example).
} 
80 percent of non-managers were appraised in the last year and whether nonmanagers have a performance-related component to their pay). The index then covers practices which ensure that employees have the opportunity to deploy their skills and tacit knowledge effectively (whether the workplace makes use of semi-autonomous or autonomous teamworking, trains workers to be functionally flexible, and involves employees in problem solving through the use of problem-solving groups or quality circles). Together, these three sets of practices cover the three strands of Appelbaum's ability-motivation-opportunity framework (Appelbaum et al. 2000). A fourth set of practices focuses on the use of organizational performance targets (whether the workplace keeps records of key performance indicators such as productivity or labor turnover, and whether it sets targets for these key performance indicators). The use of such performance targets provides the backdrop to employee-level incentive systems and is a key part of the emerging literature on data-driven management practices (Brynjolfsson and McElheran 2016a, 2016b). Finally, to capture the extent to which the workplace takes a strategic approach to HRM (Boxall, 1996), we include an indicator of whether it has a strategic plan that covers employee development, employee job satisfaction, or employee diversity. The literature finds that additive scales of this type are highly positively correlated with workplace labor productivity, partly reflecting otherwise unobserved managerial quality, and partly due to direct causal effects (Bloom, Sadun, and Van Reenen 2017; Forth and Bryson 2019; Guest, David, Michie, Conway, \& Sheehan, 2003; Huse lid 1995).

Where data are missing on one of the control variables, we impute mean values from the non-missing sample. We then incorporate an additional control variable that measures the number of covariates for which a workplace had missing data prior to imputation. ${ }^{20}$

We extend the financial performance models in a number of ways to see whether we can gain further insights into differences in age correlations with labor productivity versus financial performance. First we incorporate mean log hourly wages at the workplace to reflect labor costs: it is plausible that any negative association between older workers and productivity is compensated for by wage differentials relative to prime-age workers, such that unit labor costs are similar across employees' age. If so, wage differentials may compensate employers for poorer labor productivity among older (and younger)

\footnotetext{
20 The scale of imputation is small. As shown in Table A1, the mean number of imputed values (out of a possible maximum of nine) is 0.25 . Eighty percent of cases have no imputed values and 96 percent have no more than one. The most frequently imputed variable is the percentage of work days lost through employee sickness or absence, which is imputed in 15 percent of cases. No other variable is imputed in more than 5 percent of cases.
} 


\section{0 / BRYSON ET AL.}

workers. Second, we add labor productivity and quality of output directly into the financial performance equation to see whether this affects the age share coefficients.

The baseline model (1) therefore takes the following form where beta is the coefficient for the age shares, delta is the coefficient for age diversity, and the thetas capture the coefficients for controls taken from the HR manager while the gammas are the coefficients for the control vector variables derived from employee surveys. We can use the employee survey responses to create workplace-level means, thus enriching our analyses by taking account of time variance in employee traits not measured in the management survey which might, if excluded, confound the relationship we are trying to identify between changes in age shares and diversity and workplace performance. This vector of workplace mean variables constructed from employee responses is identified in equation (1) below as $\Delta \bar{E}_{i}$ denoting change in the workplace means:

$$
\Delta p_{i}=\beta \Delta S_{i}+\delta \Delta D_{i}+\theta \Delta X_{i}+\gamma \Delta \bar{E}_{i}+\epsilon
$$

where $\in$ is the error term.

The great advantage of a panel first-difference model compared to cross-sectional estimates is that the panel estimator nets out unobserved fixed differences across workplaces that might otherwise bias our estimates of the relationship between the age variables and workplace performance. It does so by focusing solely on that part of the variance within workplaces, thus ignoring variance across workplaces. Although we have incorporated a number of items capturing time-varying covariates our estimates remain vulnerable to omitted time-varying variables that are correlated with performance and age shares and age diversity. Furthermore, our estimates are unable to account for the potentially endogenous nature of change in the age composition of the workforce.

\section{Findings}

Tables 2-4 report standardized coefficients from workplace first-difference models for labor productivity, quality of output, and financial performance, respectively. In each table, Model 1 contains only the age share and age diversity models without controls. Model 2 incorporates the full set of controls from the management respondent and employee respondents as per equation (1). Models 3 to 7 remove blocks of variables in a stepwise fashion to see what their removal does to the age coefficients in Model 2. Model 3 removes the workforce composition controls. Model 4 removes the standard human 
TABLE 2

Change in Labor Productivity, 2004-2011

\begin{tabular}{llllllll}
\hline \hline & Model 1 & Model 2 & Model 3 & Model 4 & Model 5 & Model 6 & Model 7 \\
\hline$\Delta$ Share 50+ & $-0.216^{* *}$ & $-0.134^{*}$ & $-0.158^{*}$ & -0.117 & $-0.145^{*}$ & $-0.142^{*}$ & $-0.159^{*}$ \\
& $(-2.44)$ & $(-1.65)$ & $(-1.91)$ & $(-1.45)$ & $(-1.76)$ & $(-1.83)$ & $(-1.89)$ \\
$\Delta$ Share 16-21 & $-0.242^{* * *}$ & $-0.202^{*}$ & $-0.201^{* *}$ & $-0.222^{* *}$ & $-0.205^{*}$ & -0.180 & $-0.191^{*}$ \\
& $(-2.85)$ & $(-1.84)$ & $(-2.01)$ & $(-2.13)$ & $(-1.84)$ & $(-1.64)$ & $(-1.88)$ \\
$\Delta$ Age diversity & 0.031 & 0.067 & 0.005 & 0.060 & 0.078 & 0.058 & 0.080 \\
& $(0.29)$ & $(0.60)$ & $(0.05)$ & $(0.54)$ & $(0.67)$ & $(0.51)$ & $(0.77)$ \\
Controls & & & & & & & \\
Workforce characteristics & & Yes & & Yes & Yes & Yes & Yes \\
Productive assets & & Yes & Yes & & Yes & Yes & Yes \\
Health-related assets & & Yes & Yes & Yes & & Yes & Yes \\
Technology & & Yes & Yes & Yes & Yes & & Yes \\
Management practices & & Yes & Yes & Yes & Yes & Yes & \\
Adjusted R-sq & 0.073 & 0.256 & 0.202 & 0.230 & 0.245 & 0.238 & 0.232 \\
Observations & 290 & 290 & 290 & 290 & 290 & 290 & 290 \\
\hline
\end{tabular}

${ }^{\mathrm{a}}$ Models estimated via first differences.; ${ }^{\mathrm{b}}$ Coefficients are standardized. Controls are detailed in the text.; ${ }^{\mathrm{c}} \mathrm{T}$-statistics in parentheses. Significance: ${ }^{* *} p<0.01,{ }^{* *} p<0.05,{ }^{*} p<0.10$.

TABLE 3

Change in Quality of OutPut, 2004-2011

\begin{tabular}{llllllll}
\hline \hline & Model 1 & Model 2 & Model 3 & Model 4 & Model 5 & Model 6 & Model 7 \\
\hline$\Delta$ Share 50+ & 0.072 & 0.108 & 0.103 & 0.120 & 0.114 & 0.094 & 0.092 \\
& $(0.88)$ & $(1.25)$ & $(1.19)$ & $(1.38)$ & $(1.33)$ & $(1.13)$ & $(1.06)$ \\
$\Delta$ Share 16-21 & 0.157 & 0.143 & 0.144 & 0.147 & $0.148^{*}$ & $0.169^{*}$ & 0.139 \\
& $(1.53)$ & $(1.62)$ & $(1.57)$ & $(1.63)$ & $(1.69)$ & $(1.93)$ & $(1.51)$ \\
$\Delta$ Age diversity & -0.040 & -0.024 & -0.065 & -0.026 & -0.024 & -0.025 & -0.012 \\
& $(-0.48)$ & $(-0.35)$ & $(-0.88)$ & $(-0.36)$ & $(-0.34)$ & $(-0.35)$ & $(-0.17)$ \\
Controls & & & & & & & \\
Workforce characteristics & & Yes & & Yes & Yes & Yes & Yes \\
Productive assets & & Yes & Yes & & Yes & Yes & Yes \\
Health-related assets & & Yes & Yes & Yes & & Yes & Yes \\
Technology & & Yes & Yes & Yes & Yes & & Yes \\
Management practices & & Yes & Yes & Yes & Yes & Yes & 0.113 \\
Adjusted R-sq & 0.017 & 0.127 & 0.090 & 0.096 & 0.129 & 0.113 & 0.115 \\
Observations & 324 & 324 & 324 & 324 & 324 & 324 & 324 \\
\hline
\end{tabular}

${ }^{\mathrm{a}}$ Models estimated via first differences.; ${ }^{\mathrm{b}}$ Coefficients are standardized. Controls are detailed in the text.; ${ }^{\mathrm{c}} \mathrm{T}$-statistics in parentheses. Significance: ${ }^{*} p<0.10$.

capital-type variables (the "productive" assets). Model 5 removes the disability and absence variables (the "health-related" assets). Model 6 removes the computer use and innovation variables and Model 7 removes the HRM index. Only the coefficients for the age-related variables are presented in Tables 2-4, but the full sets of coefficients from Model 2 are provided in Appendix Table A2. 
TABLE 4

Change in Financial Performance, 2004-2011

\begin{tabular}{|c|c|c|c|c|c|c|c|c|}
\hline & $\begin{array}{l}\text { Model } \\
1\end{array}$ & $\begin{array}{l}\text { Model } \\
2\end{array}$ & $\begin{array}{l}\text { Model } \\
3\end{array}$ & $\begin{array}{l}\text { Model } \\
4\end{array}$ & $\begin{array}{l}\text { Model } \\
5\end{array}$ & $\begin{array}{l}\text { Model } \\
6\end{array}$ & $\begin{array}{l}\text { Model } \\
7\end{array}$ & $\begin{array}{l}\text { Model } \\
8\end{array}$ \\
\hline$\Delta$ Share $50+$ & $\begin{array}{l}-0.131 \\
(-1.09)\end{array}$ & $\begin{array}{l}-0.008 \\
(-0.09)\end{array}$ & $\begin{array}{l}-0.038 \\
(-0.43)\end{array}$ & $\begin{array}{l}0.001 \\
(0.01)\end{array}$ & $\begin{array}{l}-0.031 \\
(-0.32)\end{array}$ & $\begin{array}{l}-0.025 \\
(-0.29)\end{array}$ & $\begin{array}{l}-0.042 \\
(-0.38)\end{array}$ & $\begin{array}{l}0.007 \\
(0.09)\end{array}$ \\
\hline$\Delta$ Share $16-21$ & $\begin{array}{l}-0.114 \\
(-1.25)\end{array}$ & $\begin{array}{l}-0.047 \\
(-0.55)\end{array}$ & $\begin{array}{l}-0.087 \\
(-0.94)\end{array}$ & $\begin{array}{l}-0.054 \\
(-0.62)\end{array}$ & $\begin{array}{l}-0.054 \\
(-0.63)\end{array}$ & $\begin{array}{l}-0.035 \\
(-0.45)\end{array}$ & $\begin{array}{l}-0.040 \\
(-0.45)\end{array}$ & $\begin{array}{l}-0.055 \\
(-0.08)\end{array}$ \\
\hline$\Delta$ Age diversity & $\begin{array}{l}0.084 \\
(0.82)\end{array}$ & $\begin{array}{l}0.040 \\
(0.49)\end{array}$ & $\begin{array}{l}0.047 \\
(0.60)\end{array}$ & $\begin{array}{l}0.040 \\
(0.52)\end{array}$ & $\begin{array}{l}0.060 \\
(0.69)\end{array}$ & $\begin{array}{l}0.033 \\
(0.40)\end{array}$ & $\begin{array}{l}0.070 \\
(0.84)\end{array}$ & $\begin{array}{l}0.045 \\
(0.08)\end{array}$ \\
\hline \multicolumn{9}{|l|}{ Controls: } \\
\hline $\begin{array}{l}\text { Workforce } \\
\text { characteristics }\end{array}$ & & Yes & & Yes & Yes & Yes & Yes & Yes \\
\hline Productive assets & & Yes & Yes & & Yes & Yes & Yes & Yes \\
\hline Health-related assets & & Yes & Yes & Yes & & Yes & Yes & Yes \\
\hline Technology & & Yes & Yes & Yes & Yes & & Yes & Yes \\
\hline Management practices & & Yes & Yes & Yes & Yes & Yes & & Yes \\
\hline Mean wage & & & & & & & & Yes \\
\hline Adjusted R-sq & 0.009 & 0.216 & 0.199 & 0.193 & 0.190 & 0.205 & 0.159 & 0.255 \\
\hline Observations & 302 & 302 & 302 & 302 & 302 & 302 & 302 & 302 \\
\hline
\end{tabular}

${ }^{\mathrm{a}}$ Models estimated via first differences.; ${ }^{\mathrm{b}}$ Coefficients are standardized. Controls are detailed in the text.; ${ }^{\mathrm{c}} \mathrm{T}$-statistics in parentheses.

Workplace labor productivity (as measured by managers' subjective assessments) falls with an increase in the share of younger and older workers. This relationship is apparent in the raw data (Model 1), and remains apparent when controlling for the full set of controls (Model 2). However, the introduction of these controls results in a substantial reduction in the size of the older workers coefficient (from -0.216 in Model 1 to -0.134 in Model 2), such that the coefficient is only on the margins of statistical significance in Model 2. Those controls account for a sizeable portion of the variance in changes in workplace labor productivity such that the adjusted R-squared rises from 0.07 without controls to 0.26 with controls. Most controls variables have the expected signs. For example, labor productivity rises with the HRM index and with the number of workplace innovations, but falls with a rise in the share of underskilled employees.

Removing controls for other changes in workforce composition reduces the explanatory power of the model somewhat but the older worker share coefficient remains negative and statistically significant at the 10-percent level (Model 3). A similar story emerges when we remove other covariate blocks: the explanatory power of the model falls a little but the share of older workers remains negative and statistically significant in all but Model $4 .^{21}$

\footnotetext{
${ }^{21}$ Shifts in the coefficient on the share of older workers can be understood through reference to the pairwise correlations in Appendix Table A3.
} 
As mentioned previously, existing studies have not generally found older average age to be negatively associated with workplace productivity; some have found positive effects, while others have found evidence of nonlinear relationships. It is important to bear in mind the different settings in which these studies have taken place (sometimes in particular industries and none for Britain), and also to recall that our models bear down specifically on the share of older workers rather than focusing on the average age of the workforce in more general terms.

It is not just a rise in the proportion of older workers that was associated with a fall in workplace labor productivity. Increasing the share of younger workers was also negatively associated with changes in workplace labor productivity, the effect being somewhat larger than that for the share of older employees. In combination, these results are reminiscent of the steep gradient in earnings that is commonly observed in the early years of a worker's career and more-gradual decline typically observed in later years (Murphy and Welch 1990). Together, they imply that an increase in the share of workers aged 22 to 49 years (the omitted reference category) is associated with increased labor productivity.

The fact that age diversity has the potential to have both positive and negative consequences for labor productivity may explain why the findings from existing empirical studies on this issue are mixed. In our analysis change in age diversity was not significantly associated with changes in labor productivity, although the coefficient was positive across all model specifications.

Results from identical analyses for workplace performance in terms of the manager's assessment of quality of output are presented in Table 3. They are unable to account for as much of the variance in performance as the productivity models in Table 2 , the adjusted R-squared being 0.13 in the full model (Model 2). For this measure of performance, the share of older workers is always positive but never statistically significant across model specifications. The share of younger workers is also positive and in some model specifications is on the margins of statistical significance. Age diversity is negative but nonsignificant throughout.

In spite of the negative association between increases in the share of older employees and changes in labor productivity, this does not feed through to financial performance. There is no statistically significant association between the change in the share of older workers and change in financial performance. The older worker share coefficient is negative in the absence of controls but is not approaching statistical significance (Table 4, Model 1). The introduction of controls in Model 2 brings the older worker coefficient even closer to zero ( $\beta=-0.008$, with a $t$-statistic of -0.09 ). Nevertheless, the removal of blocks of variables has only a marginal impact on the older worker share coefficient 


\section{4 / BRYSON ET AL.}

in Models 3 to 7. The fact that the older worker share is not associated with financial performance does not appear to be the result of data peculiarities or model specification: the dependent variable has a similar distribution to labor productivity (see Figure 2 and Table A1) and a number of the control variables in the model of financial performance perform as we might have expected, with the adjusted R-squared rising from 0.01 to 0.22 between Model 1 and Model 2. For example, the share of underskilled workers is negative and statistically significant while the HRM index is positive and statistically significant throughout.

In the final model (Model 8), we also condition on mean log hourly wages. An increase in hourly wages is associated with an increase in workplace financial performance, perhaps reflecting improvements in productivity of workers or the quality of hires. In this model, the older worker share coefficient is very close to zero. Age diversity is not statistically significant in any of the specifications. Few existing studies have considered the relationship between age of the workforce and financial performance, with the exception of Kunze, Boehm, and Bruch (2011) and Garnero, Kampelmann, and Rycx (2014), who also find no significant direct effect.

Finally, we condition on labor productivity and product/service quality (results not shown for brevity). Both measures are positively associated with financial performance, as one would expect, but the coefficients on all three age-related variables remain small and nonsignificant after their addition.

\section{Summary and Conclusions}

In this article, we have used panel data for private-sector workplaces from the 2004-2011 WERS to establish the association between changes in age shares and age diversity with three measures of changes in workplace performance. The analysis focuses on within-workplace change and controls for unobserved, fixed, workplace traits and a range of observed, time-varying characteristics that might conceivably affect workforce age composition and workplace performance.

In general, there are weak or no associations between changes in age shares, changes in age diversity, and workplace performance over the period. There is some evidence that both a higher percentage of older employees, and a higher percentage of younger employees, result in a reduction in labor productivity, but this does not carry through to financial performance. One possible reason for this is that workplaces benefit from their older workers in other ways, for example, by helping to reduce labor costs, thus compensating for lower older worker productivity. This could be the case if, for example, older workers 
received lower wages, or could result from lower expenditure on training of older workers. However, we incorporate changes in hourly wages, the major component in labor costs, and this does not affect the association.

The significance and magnitude of the relationships between the age variables and workplace performance did not shift decisively with the inclusion of variables capturing other aspects of workplace demographics nor proxies for various aspects of human capital. The inclusion of such variables did, however, increase the amount of variance in performance accounted for by the models.

Although other studies find some effects of age shares, average age, and age diversity on organizational performance, our study makes three specific contributions to the existing literature. First, by categorizing the workforce into specific age ranges, instead of using a measure of mean age, which has been the universal approach elsewhere (see Table 1), our analysis is able to inform employers and policymakers about the potential implications of hiring workers at different stages of their career. Our results suggest that there is a "productivity penalty" from hiring older workers, but that hiring very young workers impairs productivity to an even greater extent. Second, by investigating the association between workforce age composition and a range of workplace performance indicators (labor productivity, product or service quality, and financial performance) we go beyond many of the existing studies, which typically focus only on productivity effects. Only two studies in our review of the literature have studied the impact on financial performance (Garnero, Kampelmann, and Rycx 2014; Kunze, Boehm, and Bruch 2011), and our results add to this small body of existing evidence that suggests that an older workforce does not ultimately have any significant direct effect on the bottom line. Third, ours is the first investigation of these issues for Britain. The UK government has engaged in a series of campaigns to encourage employers to increase their employment of older workers but, until now, empirical evidence for employers on the returns to doing so came from samples of firms in other institutional settings. There is no strong reason to suspect that Britain is unique, although it did adopt age discrimination legislation somewhat later than many other countries. Our evidence indicates that age-related workplace demographics do not play a major role in determining the success of private-sector workplaces in Britain.

Of course, there are a number of limitations to our analyses. Results could be sensitive to the inclusion of additional time-varying control variables, such as better controls for changes in capital intensity, and there may be nonlinear effects of age diversity which we have not examined. Our subjective measures of workplace performance (although the best available) may be subject to measurement error, potentially biasing the associations with workforce age 


\section{6 / BRYSON ET AL.}

downward. Another drawback to our study is that the panel sample sizes are quite small, making it difficult to obtain precise estimates of what appear to be relatively small effects in most instances. However, our study has the advantage of being able to call upon a broad range of performance measures and a high-quality sample. Our results suggest that employers should be open to exhortations to increase their employment of older workers.

\section{REFERENCES}

Appelbaum, Eileen, Thomas Bailey, Peter Berg, and Arne L. Kalleberg. 2000. Manufacturing Advantage: Why High-Performance Work Systems Pay Off. London: ILR Press.

Backes-Gellner, Uschi, and Stephan Veen. 2013. "Positive Effects of Ageing and Age Diversity in Innovative Companies-Large-Scale Empirical Evidence on Company Productivity." Human Resource Management Journal 23(3): 279-95.

Becker, Gary S. 1962. "Investment in Human Capital: A Theoretical Analysis." Journal of Political Economy 70(5, Part 2): 9-49.

Bertrand, Marianne, Sandra E. Black, Sissel Jensen, and Adriana Lleras-Muney. 2014. "Breaking the Glass Ceiling? The Effect of Board Quotas on Female Labor Market Outcomes in Norway.” NBER Working Paper No. 20256. Cambridge, MA: National Bureau of Economic Research.

Bloom, Nicholas, and John Van Reenen. 2011. "Human Resource Management and Productivity." In Handbook of Labor Economics, Vol. 4, edited by Orley Ashenfelter and David Card, pp. 1697-1767. Amsterdam: Elsevier.

—_ Raffaela Sadun, and John Van Reenen. 2017. "Management as a Technology?" NBER Working Paper No. 22327. Cambridge, MA: National Bureau of Economic Research.

Borsch-Supan, Axel and Matthias Weiss. 2007. "Productivity and Age: Evidence from Work Teams at the Assembly Line”, Munich Center for the Economics of Ageing, Discussion Paper 148-2007.

Boxall, Peter. 1996. "The Strategic HRM Debate and the Resource-Based View of the Firm." Human Resource Management Journal 6(3): 59-75.

Brynjolfsson, Erik, and Kristina McElheran. 2016a. "Data in Action: Data-Driven Management in US Manufacturing." CES Working Paper 16-06. Washington DC: Centre for Economic Studies.

- and 2016b. "The Rapid Adoption of Data-Driven Decision Making." American Economic Review: Papers and Proceedings 106(5): 133-39.

Burgmann, Lucy. 2013. "Engaging and Retaining Older Workers." AIM Insights Discussion Paper. Sydney: Australian Institute of Management.

Business in the Community. 2017. One Million More: Mobilising Business to Make the Most of the Opportunity of Older Workers and an Ageing Population. London: BITC.

Canduela, Jesus, Matthew Dutton, Steve Johnson, Colin Lindsay, Ronald W. McQuaid, and Robert Raeside. 2012. "Ageing, Skills and Participation in Work-Related Training in Britain: Assessing the Position of Older Workers." Work, Employment and Society 26(1): 42-60.

Craig, T. 2009. "Older Workers Adding Value -Four Case Studies." Personnel Today. https://www.person neltoday.com/hr/older-workers-adding-value-four-case-studies/(accessed August 12, 2019).

Department for Business Innovation and Skills. 2015. Workplace Employee Relations Survey 2011 [computer file]. 5th Edition. Colchester, UK: UK Data Archive [distributor]. SN: 7226, https://doi.org/ https://doi.org/10.5255/UKDA-SN-7226-7.

Department for Work and Pensions. 2007. Flexible Working: Age Positive Guide. London: DWP.

Department for Work and Pensions. 2015. Statistics on Older Workers by Sector. London: DWP.

Department for Work and Pensions. 2017. Fuller Working Lives: A Partnership Approach. London: DWP.

Forth, John, and Alex Bryson. 2019. "Management Practices and SME Performance." Scottish Journal of Political Economy 66(4): 527-58. 
and Robert McNabb. 2008. "Workplace Performance: A Comparison of Subjective and Objective Measures in the 2004 Workplace Employment Relations Survey." Industrial Relations Journal 39(2): 104-23.

Huselid, Mark. 1995. "The Impact of Human Resource Management Practices on Turnover, Productivity and Corporate Financial Performance.” Academy of Management Journal 38(3): 635-72.

Garnero, Andrea, Stephan Kampelmann, and François Rycx. 2014. "The Heterogeneous Effects of Workforce Diversity on Productivity.” Wages and Profits, Industrial Relations 53(3): 430-77.

George, Anitha, Hilary Metcalf, Leila Tufekci, and David Wilkinson. 2015. Understanding age and the labour market. New York, NY: Joseph Rowntree Foundation.

Goff, Brian L., Robert E. McCormick, and Robert D. Tollison. 2002. "Racial Integration as an Innovation: Empirical Evidence from Sports Leagues." The American Economic Review 92(1): 16-26.

Gratton, Lynda and Andrew Scott. 2016. The 100-Year Life: Living and Working in an Age of Longevity. London: Bloomsbury.

Grund, Christian and Niels Westergaard-Nielsen. 2008. "Age Structure of the Workforce and Firm Performance." International Journal of Manpower 29(5): 410-22.

Guest, David E., Jonathan Michie, Neil Conway, and Maura Sheehan. 2003. "Human Resource Management and Corporate Performance in the UK." British Journal of Industrial Relations 41(2): 291-314.

Ilmakunnas, Pekka, and Seija Ilmakunnas. 2011. "Diversity at the Workplace: Whom Does It Benefit?" De Economist 159: 223-255.

Ilmakunnas, Pekka, Mika Maliranta, and Jari Vainiomäki (2004) "The roles of employer and employee characteristics in plant productivity." Journal of Productivity Analysis, 21(3): 249-276.

Kremer, Michael. 1993. "The O-Ring Theory of Economic Development." The Quarterly Journal of Economics 108(3): 551-75.

Kunze, Florian, Stephan A. Boehm, and Heike Bruch. 2011. "Age Dversity, Age Discrimination Climate and Performance Consequences-Across-Organizational Study." Journal of Organizational Behavior 32(2): 264-2=90.

Lazear, Edward P. 1998. Personnel Economics for Managers. New York: John Wiley and Sons. . 1999. "Globalisation and the Market for Team-mates." The Economic Journal 109: 15-40.

Leonard, Jonathan S., and David I. Levine. 2003. "Diversity, Discrimination and Performance." Institute for Research on Labor and Employment Working Paper, UC Berkeley. Berkeley: University of California.

Machin, Stephen J., and Mark B. Stewart. 1996. "Trade Unions and Financial Performance." Oxford Economic Papers 49: 213-41.

— ments." Journal of Applied Econometrics 5: 327-50.

Murphy, Kevin M and Finis Welch. 1990. "Empirical Age-Earnings Profiles.” Journal of Labor Economics 8(2): 202-29.

Neumark, David, Ian Burn, and Patrick Button. 2019. "Is it Harder for Older Workers to Find Jobs? New and Improved Evidence from a Field Experiment." Journal of Political Economy 127(2): 922-70.

Organisation for Economic Cooperation and Development (OECD). 2019. Employment Outlook 2019. Paris: OECD.

Office for National Statistics (ONS). 2015. Participation Rates in the UK-2014-3. Older People. London: Office for National Statistics.

Office for National Statistics (ONS). 2016. UK Labour Market: October 2016. London: Office for National Statistics.

Parrotta, Pierpaolo, Dario Pozzoli, and Mariola Pytlikova. 2014. "Labor Diversity and Firm Productivity." European Economic Review 66: 144-79.

Rosen, Sherwin. 1972. "Learning and Experience in the Labour Market." Journal of Human Resources 7(3): 326-42.

Smeaton, Deborah, Sandra Vegeris, and Melahat Sahin-Dikmen. 2009. “Older Workers: Employment Preferences, Barriers and Solutions." Equality and Human Rights Commission, Research Report 43. Manchester, UK: Equality and Human Rights Commission. 


\section{8 / BRYSON ET AL.}

Van, Wanrooy Brigid, Helen Bewley, Alex Bryson, John Forth, Stephanie Freeth, Lucy Stokes, and Stephen Wood. 2013. Employment Relations in the Shadow of Recession: Findings from the 2011 Workplace Employment Relations Survey. Basingstoke: Palgrave Macmillan.

Yeomans, Liz. 2011. "An Update of the Literature on Age and Employment." Health and Safety Executive, Research Report RR832. Buxton, UK: Health and Safety Executive. 
APPENDIX A

\section{Additional Tables}

TABLE A1

Descriptive Statistics

\begin{tabular}{|c|c|c|c|c|c|c|}
\hline \multirow[b]{2}{*}{ Unstandardized Variables: } & \multicolumn{2}{|l|}{2004} & \multicolumn{2}{|l|}{2011} & \multicolumn{2}{|c|}{ First difference } \\
\hline & Mean & S.D. & Mean & S.D. & Mean & S.D. \\
\hline $\begin{array}{l}\text { Labor productivity (subjective rating: } 1=\mathrm{A} \text { lot } \\
\text { below average for the industry; } 2=\text { Below } \\
\text { average; } 3=\text { About average; } 4=\text { Above } \\
\text { average; } 5=\mathrm{A} \text { lot above average) }\end{array}$ & 3.455 & 0.739 & 3.490 & 0.707 & 0.034 & 0.959 \\
\hline Quality of product or service (scored as above) & 4.093 & 0.657 & 4.046 & 0.747 & -0.046 & 0.855 \\
\hline Financial performance (scored as above) & 3.536 & 0.813 & 3.540 & 0.845 & 0.003 & 1.064 \\
\hline Share of employees aged $50+$ & 0.217 & 0.159 & 0.273 & 0.160 & 0.056 & 0.163 \\
\hline Share of employees aged $16-21$ & 0.102 & 0.154 & 0.082 & 0.138 & -0.020 & 0.109 \\
\hline Age diversity index (see text for details) & 0.393 & 0.151 & 0.433 & 0.117 & 0.040 & 0.146 \\
\hline Ln(number of employees) & 4.290 & 1.687 & 4.319 & 1.676 & 0.029 & 0.793 \\
\hline Share of employees female & 0.468 & 0.300 & 0.477 & 0.282 & 0.008 & 0.132 \\
\hline $\begin{array}{l}\text { Share of employees from a non-white ethnic } \\
\text { group }\end{array}$ & 0.062 & 0.129 & 0.086 & 0.162 & 0.024 & 0.131 \\
\hline $\begin{array}{l}\text { Share of employees working part time (fewer } \\
\text { than } 30 \text { hours per week) }\end{array}$ & 0.268 & 0.290 & 0.270 & 0.281 & 0.002 & 0.167 \\
\hline $\begin{array}{l}\text { Union density (union members as a share of all } \\
\text { employees) }\end{array}$ & 0.174 & 0.273 & 0.151 & 0.249 & -0.023 & 0.191 \\
\hline $\begin{array}{l}\text { Share of employees using computers in normal } \\
\text { work duties }\end{array}$ & 0.507 & 0.377 & 0.587 & 0.372 & 0.081 & 0.306 \\
\hline $\begin{array}{l}\text { Number of managerial innovations introduced } \\
\text { over past } 2 \text { years (introduction of performance- } \\
\text { related pay; introduction of new technology; } \\
\text { change in working time; change in work } \\
\text { organization; change in work techniques; } \\
\text { introduction of employee involvement; } \\
\text { introduction of new or improved product or } \\
\text { process) }\end{array}$ & 2.852 & 1.955 & 2.769 & 1.964 & -0.083 & 2.277 \\
\hline $\begin{array}{l}\text { Ln(share of employees with a work-limiting } \\
\text { disability) }\end{array}$ & -4.236 & 0.617 & -4.197 & 0.667 & 0.039 & 0.800 \\
\hline $\begin{array}{l}\mathrm{Ln}(\% \text { of work days lost through employee } \\
\text { sickness or absence over past } 12 \text { months })\end{array}$ & -3.193 & 0.636 & -3.194 & 0.687 & -0.001 & 0.86 \\
\hline $\begin{array}{l}\text { Share of higher-skilled employees (managers, } \\
\text { professionals, associate professional and } \\
\text { technical, skilled trades) }\end{array}$ & 0.379 & 0.294 & 0.403 & 0.299 & 0.024 & 0.211 \\
\hline $\begin{array}{l}\text { Mean highest-qualification score }{ }^{+,++, a}(0=\text { No } \\
\text { qualifications; } 1=\text { Unspecified; } 2=\text { GCSE D-G; } \\
3=\text { GCSE A-C; } 4=1 \text { A-level; } 5=2+\text { A- } \\
\text { levels; } 6=\text { First degree; } 7=\text { Higher degree })\end{array}$ & 3.148 & 1.323 & 3.249 & 1.385 & 0.100 & 1.086 \\
\hline
\end{tabular}


TABLE A1 (CONTINUED)

\begin{tabular}{|c|c|c|c|c|c|c|}
\hline \multirow[b]{2}{*}{ Unstandardized Variables: } & \multicolumn{2}{|l|}{2004} & \multicolumn{2}{|l|}{2011} & \multicolumn{2}{|c|}{ First difference } \\
\hline & Mean & S.D. & Mean & S.D. & Mean & S.D. \\
\hline $\begin{array}{l}\text { Mean tenure score }{ }^{+,++, \mathrm{a}}(1=0-11 \text { months; } \\
\begin{array}{l}2=12-23 \text { months; } 3=24-59 \text { months; } \\
4=60-119 \text { months; } 5=10 \text { years or more })\end{array}\end{array}$ & 3.163 & 0.788 & 3.507 & 0.798 & 0.344 & 0.901 \\
\hline $\begin{array}{l}\text { Share of employees who consider their work } \\
\text { skills to be lower than those needed for their } \\
\text { present job }\end{array}$ & 0.053 & 0.093 & 0.050 & 0.088 & -0.003 & 0.125 \\
\hline $\begin{array}{l}\text { HRM index (count of: autonomous teamworking; } \\
\text { functional flexibility; extensive training; } \\
\text { problem-solving groups; extensive performance } \\
\text { appraisal; Investor in People award; incentive } \\
\text { pay scheme; extensive target-setting; extensive } \\
\text { monitoring of targets; strategic plan with } \\
\text { employee focus) }\end{array}$ & 4.904 & 2.255 & 5.296 & 2.337 & 0.392 & 2.196 \\
\hline Mean hourly wage ${ }^{+,++, a}$ (£/hour) & 10.025 & 5.709 & 13.586 & 10.539 & 3.561 & 10.043 \\
\hline $\begin{array}{l}\text { Number of missing values across all controls } \\
\text { (range: } 0-9 \text { ) }\end{array}$ & 0.241 & 0.495 & 0.259 & 0.615 & 0.019 & 0.750 \\
\hline Observations $^{+,++, \text {a }}$ & 324 & & 324 & & 324 & \\
\hline
\end{tabular}

${ }^{+}=$generated from linked Survey of Employees.; ${ }^{++}=$Except labor productivity $(\mathrm{N}=290)$ and financial performance $(\mathrm{N}=302)$.

TABLE A2

Coefficients from Fully Specified Models

\begin{tabular}{|c|c|c|c|}
\hline Change in: & $\begin{array}{l}\text { Change in Labor } \\
\text { Productivity }\end{array}$ & $\begin{array}{l}\text { Change in } \\
\text { Quality of } \\
\text { Output }\end{array}$ & $\begin{array}{l}\text { Change in } \\
\text { Financial } \\
\text { Performance }\end{array}$ \\
\hline Share of employees aged 50+ & $\begin{array}{l}-0.134^{*} \\
(-1.65)\end{array}$ & $\begin{array}{l}0.108 \\
(1.25)\end{array}$ & $\begin{array}{l}-0.008 \\
(-0.09)\end{array}$ \\
\hline Share of employees aged 16-21 & $\begin{array}{l}-0.202^{*} \\
(-1.84)\end{array}$ & $\begin{array}{l}0.143 \\
(1.62)\end{array}$ & $\begin{array}{l}-0.047 \\
(-0.55)\end{array}$ \\
\hline Age diversity index & $\begin{array}{l}0.067 \\
(0.60)\end{array}$ & $\begin{array}{l}-0.024 \\
(-0.35)\end{array}$ & $\begin{array}{l}0.040 \\
(0.49)\end{array}$ \\
\hline Ln(number of employees) & $\begin{array}{l}-0.240 \\
(-1.14)\end{array}$ & $\begin{array}{l}-0.262 \\
(-1.18)\end{array}$ & $\begin{array}{l}0.326 \\
(1.33)\end{array}$ \\
\hline Share of employees female & $\begin{array}{l}-0.214^{*} \\
(-1.90)\end{array}$ & $\begin{array}{l}-0.133 \\
(-1.04)\end{array}$ & $\begin{array}{l}0.087 \\
(0.62)\end{array}$ \\
\hline $\begin{array}{l}\text { Share of employees from a non-white ethnic } \\
\text { group }\end{array}$ & $\begin{array}{l}0.077 \\
(1.45)\end{array}$ & $\begin{array}{l}0.011 \\
(0.29)\end{array}$ & $\begin{array}{l}0.024 \\
(0.35)\end{array}$ \\
\hline
\end{tabular}


TABLE A2 (CONTINUEd)

\begin{tabular}{|c|c|c|c|}
\hline Change in: & $\begin{array}{l}\text { Change in Labor } \\
\text { Productivity }\end{array}$ & $\begin{array}{l}\text { Change in } \\
\text { Quality of } \\
\text { Output }\end{array}$ & $\begin{array}{l}\text { Change in } \\
\text { Financial } \\
\text { Performance }\end{array}$ \\
\hline Share of employees working part time & $\begin{array}{l}-0.233^{* *} \\
(-2.18)\end{array}$ & $\begin{array}{l}-0.132 \\
(-1.05)\end{array}$ & $\begin{array}{l}-0.207 \\
(-1.65)\end{array}$ \\
\hline Union density & $\begin{array}{l}-0.060 \\
(-0.65)\end{array}$ & $\begin{array}{l}0.146^{*} \\
(1.74)\end{array}$ & $\begin{array}{l}-0.121 \\
(-1.09)\end{array}$ \\
\hline Share of employees using computers & $\begin{array}{l}-0.056 \\
(-0.64)\end{array}$ & $\begin{array}{l}-0.067 \\
(-0.68)\end{array}$ & $\begin{array}{l}-0.007 \\
(-0.07)\end{array}$ \\
\hline $\begin{array}{l}\text { Number of managerial innovations introduced } \\
\text { over past } 2 \text { years }\end{array}$ & $\begin{array}{l}0.133^{* *} \\
(2.41)\end{array}$ & $\begin{array}{l}0.104 \\
(1.14)\end{array}$ & $\begin{array}{l}0.118 \\
(1.38)\end{array}$ \\
\hline $\begin{array}{l}\mathrm{Ln} \text { (share of employees with a work-limiting } \\
\text { disability) }\end{array}$ & $\begin{array}{l}-0.053 \\
(-0.60)\end{array}$ & $\begin{array}{l}0.036 \\
(0.63)\end{array}$ & $\begin{array}{l}-0.080 \\
(-1.13)\end{array}$ \\
\hline $\begin{array}{l}\mathrm{Ln}(\% \text { of work days lost through employee } \\
\text { sickness or absence over past } 12 \text { months })\end{array}$ & $\begin{array}{l}-0.074 \\
(-1.06)\end{array}$ & $\begin{array}{l}-0.001 \\
(-0.01)\end{array}$ & $\begin{array}{l}-0.114^{*} \\
(-1.96)\end{array}$ \\
\hline Share of higher-skilled employees & $\begin{array}{l}0.022 \\
(0.17)\end{array}$ & $\begin{array}{l}-0.077 \\
(-0.69)\end{array}$ & $\begin{array}{l}-0.004 \\
(-0.03)\end{array}$ \\
\hline Mean qualifications score ${ }^{+}$ & $\begin{array}{l}0.011 \\
(0.12)\end{array}$ & $\begin{array}{l}-0.088 \\
(-1.07)\end{array}$ & $\begin{array}{l}-0.002 \\
(-0.02)\end{array}$ \\
\hline Mean tenure score ${ }^{+}$ & $\begin{array}{l}0.046 \\
(0.78)\end{array}$ & $\begin{array}{l}-0.015 \\
(-0.32)\end{array}$ & $\begin{array}{l}-0.001 \\
(-0.01)\end{array}$ \\
\hline Share of employees underskilled for their job ${ }^{+}$ & $\begin{array}{l}-0.106^{* *} \\
(-2.55)\end{array}$ & $\begin{array}{l}-0.078^{* * *} \\
(-2.71)\end{array}$ & $\begin{array}{l}-0.098^{*} \\
(-1.94)\end{array}$ \\
\hline HRM index & $\begin{array}{l}0.181^{* *} \\
(2.35)\end{array}$ & $\begin{array}{l}0.125^{*} \\
(1.74)\end{array}$ & $\begin{array}{l}0.287^{* * *} \\
(3.12)\end{array}$ \\
\hline Number of missing values across all controls & $\begin{array}{l}-0.146 \\
(-1.58)\end{array}$ & $\begin{array}{l}-0.014 \\
(-0.13)\end{array}$ & $\begin{array}{l}-0.253^{* *} \\
(-2.27)\end{array}$ \\
\hline Adjusted R-sq & 0.256 & 0.127 & 0.216 \\
\hline Observations & 290 & 324 & 302 \\
\hline
\end{tabular}

${ }^{\mathrm{a}}$ Models estimated via first differences.; ${ }^{\mathrm{b}}$ Coefficients are standardized.; ${ }^{\mathrm{c}} \mathrm{T}$-statistics in parentheses. Significance: ${ }^{* * *} p<0.01,{ }^{* *} p<0.05,{ }^{*} p<0.10 .{ }^{\mathrm{d}+}=$ generated from linked Survey of Employees.

TABLE A3

Pairwise Correlations between Age Shares and Control Variables

\begin{tabular}{|c|c|c|c|c|c|c|}
\hline & \multicolumn{2}{|c|}{$\begin{array}{l}\text { Share of } \\
\text { Employees } \\
\text { aged } 50+\end{array}$} & \multicolumn{2}{|c|}{$\begin{array}{l}\text { Share of } \\
\text { Employees } \\
\text { aged 16-21 }\end{array}$} & \multicolumn{2}{|c|}{$\begin{array}{l}\text { Age } \\
\text { Diversity }\end{array}$} \\
\hline & $\mathrm{r}$ & sig. & $\mathrm{r}$ & sig. & $\mathrm{r}$ & sig. \\
\hline Share of employees aged $50+$ & 1.000 & & & & & \\
\hline Share of employees aged $16-21$ & -0.310 & $* * *$ & 1.000 & & & \\
\hline Age diversity index (see text for details) & 0.476 & $* * *$ & 0.447 & $* * *$ & 1.000 & \\
\hline Ln(number of employees) & -0.072 & & 0.047 & & 0.082 & \\
\hline Share of employees female & -0.011 & & 0.226 & $* * *$ & 0.063 & \\
\hline Share of employees from a non-white ethnic group & -0.155 & $* *$ & -0.072 & & -0.228 & $* *$ \\
\hline
\end{tabular}




\begin{tabular}{|c|c|c|c|c|c|c|}
\hline & \multicolumn{2}{|c|}{$\begin{array}{l}\text { Share of } \\
\text { Employees } \\
\text { aged } 50+\end{array}$} & \multicolumn{2}{|c|}{$\begin{array}{l}\text { Share of } \\
\text { Employees } \\
\text { aged } 16-21\end{array}$} & \multicolumn{2}{|c|}{$\begin{array}{l}\text { Age } \\
\text { Diversity }\end{array}$} \\
\hline & $\mathrm{r}$ & sig. & $\mathrm{r}$ & sig. & $\mathrm{r}$ & sig. \\
\hline $\begin{array}{l}\text { Share of employees working part time (fewer than } 30 \text { hours } \\
\text { per week) }\end{array}$ & 0.027 & & 0.525 & $* * *$ & 0.384 & $* * *$ \\
\hline Union density (union members as a share of all employees) & 0.191 & $* * *$ & -0.065 & & 0.129 & $* * *$ \\
\hline Share of employees using computers in normal work duties & -0.089 & & -0.156 & ** & -0.211 & $* * *$ \\
\hline $\begin{array}{l}\text { Number of managerial innovations introduced over past } \\
2 \text { years (introduction of performance-related pay; } \\
\text { introduction of new technology; change in working time; } \\
\text { change in work organization; change in work techniques; } \\
\text { introduction of employee involvement; introduction of new } \\
\text { or improved product or process) }\end{array}$ & -0.237 & *** & 0.041 & & -0.133 & * \\
\hline Ln(share of employees with a work-limiting disability) & 0.137 & $* *$ & -0.030 & & 0.127 & $* *$ \\
\hline $\begin{array}{l}\mathrm{Ln}(\% \text { of work days lost through employee sickness or } \\
\text { absence over past } 12 \text { months })\end{array}$ & -0.024 & & -0.037 & & -0.015 & \\
\hline $\begin{array}{l}\text { Share of higher-skilled employees (managers, professionals, } \\
\text { associate professional and technical, skilled trades) }\end{array}$ & -0.034 & & -0.282 & $* * *$ & -0.285 & $* * *$ \\
\hline $\begin{array}{l}\text { Mean highest-qualification score }{ }^{+}(0=\text { No qualifications; } \\
1=\text { Unspecified; } 2=\text { GCSE D-G; } 3=\text { GCSE A-C; } 4=1 \\
\text { A-level; } 5=2+\text { A-levels; } 6=\text { First degree; } 7=\text { Higher } \\
\text { degree) }\end{array}$ & -0.255 & $* * *$ & -0.037 & & -0.360 & $* * *$ \\
\hline $\begin{array}{l}\text { Mean tenure score }{ }^{+}(1=0-11 \text { months; } 2=12-23 \text { months; } \\
3=24-59 \text { months; } 4=60-119 \text { months; } 5=10 \text { years or } \\
\text { more })\end{array}$ & 0.368 & $* * *$ & -0.325 & $* * *$ & 0.096 & \\
\hline Share of employees under-skilled for their job ${ }^{+}$ & 0.014 & & 0.079 & & 0.080 & \\
\hline $\begin{array}{l}\text { HRM index (count of: autonomous teamworking; functional } \\
\text { flexibility; extensive training; problem-solving groups; } \\
\text { extensive performance appraisal; Investor in People award; } \\
\text { incentive pay scheme; extensive target-setting; extensive } \\
\text { monitoring of targets; strategic plan with employee focus) }\end{array}$ & -0.206 & *** & 0.028 & & -0.092 & \\
\hline Mean hourly wage ${ }^{+}(\mathfrak{£} /$ hour $)$ & -0.086 & & -0.250 & $* * *$ & -0.288 & $* * *$ \\
\hline Number of missing values across all controls & 0.033 & & -0.010 & & 0.021 & \\
\hline Observations & 324 & & 324 & & 324 & \\
\hline
\end{tabular}

${ }^{\mathrm{a}}$ Variables are unstandardized and shown in levels (2004 and 2011 pooled).; ${ }^{\mathrm{b}}+=$ generated from linked Survey of Employees.; ${ }^{\mathrm{c} S i g n i f i c a n c e: ~}{ }^{* *} p<0.01,{ }^{* *} p<0.05,{ }^{*} p<0.10$. 